$\mathrm{Oz}$

Volume 28

Article 1

$1-1-2006$

\title{
Table of Contents and Prologue
}

Nicole Ellis

Jason Fedak

Gabe McKee

Follow this and additional works at: https://newprairiepress.org/oz

cc) (1) $(9)$

This work is licensed under a Creative Commons Attribution-Noncommercial-No Derivative Works 4.0 License.

Recommended Citation

Ellis, Nicole; Fedak, Jason; and McKee, Gabe (2006) "Table of Contents and Prologue," Oz: Vol. 28. https://doi.org/10.4148/2378-5853.1426

This Front Matter is brought to you for free and open access by New Prairie Press. It has been accepted for inclusion in $\mathrm{Oz}$ by an authorized administrator of New Prairie Press. For more information, please contact cads@kstate.edu. 


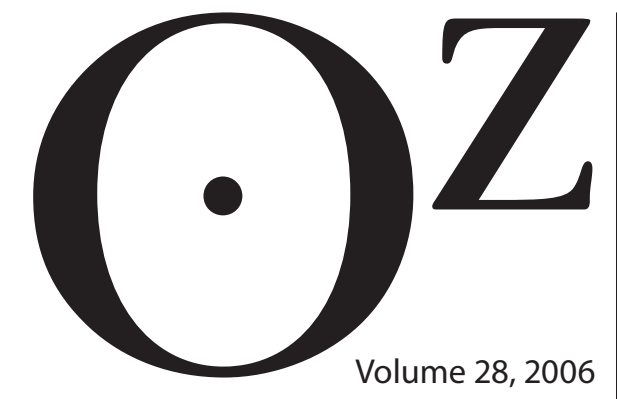




\section{Contents}

\section{Editors}

Nicole Ellis

Jason Fedak

Gabe McKee

\section{Staff}

Brent Hansen

Sam Loring

\section{Faculty Advisors}

R. Todd Gabbard

Raymond Streeter

\section{Prologue Image}

Dan Pitera,

Detroit Collaborative Design Center

$O z$ is a nonprofit journal edited, designed and produced annually by students in the Kansas State University College of Architecture, Planning, and Design. Please address inquiries to:

Managing Editor, $\mathrm{Oz}$

13 Seaton Hall

Manhattan, KS 66506-2901

ISSN 0888-7802

Copyright $\odot 2006 \mathrm{Oz}$
4 Building to Learn/Learning to Build

10 A Church in Filadelfia, Costa Rica

12 Trailer Wrap

16 Constructed Landscape

18 Paper Tube Emergency Shelters

20 Recycling the Margins

24 Vacillations Between Discrete and Ecological Thinking

30 Present to Future

36 The Bat Signal

40 Architecture Held Suspect

46 Free Shelter

$48 \quad$ House of Dance and Feathers

54 Onward and Upward
Sergio Palleroni

Jae Cha

Michael Hughes and Bruce Wrightsman

Michael Hughes

Shigeru Ban

Shannon Chris

Stephen Luoni

Larry Bowne and Patrick Rhodes

Bryan Bell

Dan Pitera

The Mad Housers

Project Locus

bild DESIGN 


\section{Prologue}

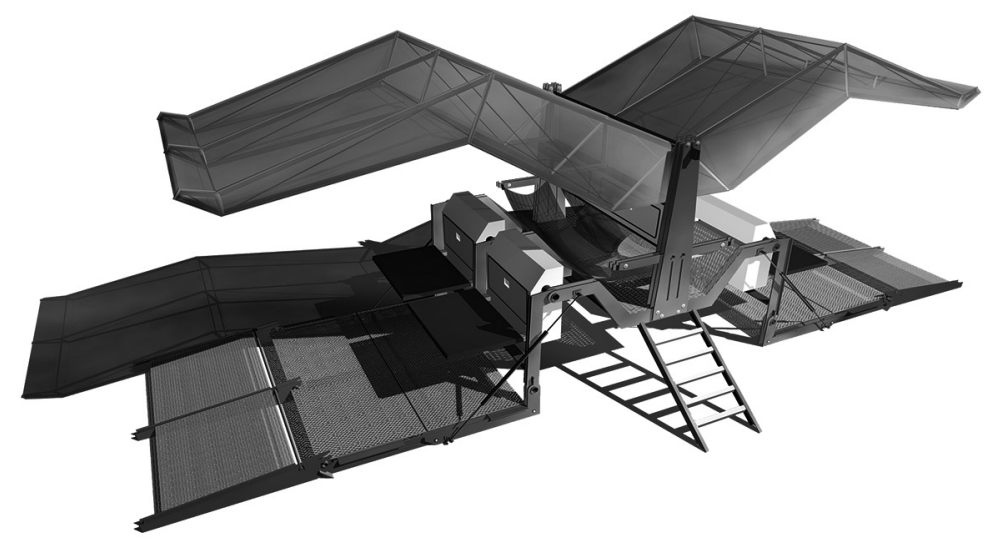

Design, as a practice or profession, is typically viewed as a humanitarian art. Designers produce cities, buildings, paintings, sculpture, landscapes, and household objects that are gifts to enrich the world. Historically design services have been commissioned by wealthy patrons seeking monuments of great importance and beauty; art pieces for all of society to enjoy. What happens when designers concentrate on making small contributions to society instead? Since design can be bought and sold, why not donate it? When humanitarian designers lend their services to the underserved population, the results seem to surpass aesthetic qualities to touch the world on a deeply human level.

...the built environment is not all about the aesthetics, but rather what the space accomplishes.

-Brian Copeland

In this issue we will examine the theoretical basis for humanitarian design, and why it is important to enrich the lives of the underserved.

N. Ellis/J. Fedak/G. McKee, Editors 